ARTICLE

DOI: $10.1038 /$ s41467-018-03153-8

\title{
Solid-phase synthesis of protein-polymers on reversible immobilization supports
}

\author{
Hironobu Murata ${ }^{1}$, Sheiliza Carmali ${ }^{1,4}$, Stefanie L. Baker ${ }^{1,2}$, Krzysztof Matyjaszewski ${ }^{1,4}$ \& Alan J. Russell $1,2,3,4,5$
}

Facile automated biomacromolecule synthesis is at the heart of blending synthetic and biologic worlds. Full access to abiotic/biotic synthetic diversity first occurred when chemistry was developed to grow nucleic acids and peptides from reversibly immobilized precursors. Protein-polymer conjugates, however, have always been synthesized in solution in multistep, multi-day processes that couple innovative chemistry with challenging purification. Here we report the generation of protein-polymer hybrids synthesized by protein-ATRP on reversible immobilization supports (PARIS). We utilized modified agarose beads to covalently and reversibly couple to proteins in amino-specific reactions. We then modified reversibly immobilized proteins with protein-reactive ATRP initiators and, after ATRP, we released and analyzed the protein polymers. The activity and stability of PARIS-synthesized and solutionsynthesized conjugates demonstrated that PARIS was an effective, rapid, and simple method to generate protein-polymer conjugates. Automation of PARIS significantly reduced synthesis/purification timelines, thereby opening a path to changing how to generate protein-polymer conjugates.

\footnotetext{
${ }^{1}$ Center for Polymer-Based Protein Engineering, Carnegie Mellon University, 5000 Forbes Avenue, Pittsburgh, PA 15213, USA. ${ }^{2}$ Department of Biomedical Engineering, Scott Hall 4N201, Carnegie Mellon University, 5000 Forbes Avenue, Pittsburgh, PA 15213, USA. ${ }^{3}$ Disruptive Health Technology Institute, Carnegie Mellon University, 5000 Forbes Avenue, Pittsburgh, PA 15213, USA. ${ }^{4}$ Department of Chemistry, Carnegie Mellon University, 4400 Fifth Avenue, Pittsburgh, PA 15213, USA. ${ }^{5}$ Department of Chemical Engineering, Carnegie Mellon University, 5000 Forbes Avenue, Pittsburgh, PA 15213, USA.

Correspondence and requests for materials should be addressed to A.J.R. (email: alanrussell@cmu.edu)
} 
T hrough pioneering work on PEGylated proteins ${ }^{1,2}$, where a chain of polyethylene glycol (PEG) is coupled to a biomolecule, the merger of the synthetic and biologic worlds has saved countless lives and driven the application of biocatalysis in a variety of industries ${ }^{1,3-7}$. Protein PEGylation takes place in solution-based grafting-to syntheses where polymers are reacted with the protein surface ${ }^{8,9}$. This approach usually requires a large excess of polymer, is not easily controlled, and the density of modification can be limited by steric hindrance ${ }^{10}$. In the last decade, alternative routes to engineer the structure and function of proteins by growing polymers from their surfaces have been developed ${ }^{11-15}$. One common grafting-from approach uses atomtransfer radical polymerization (ATRP) from initiators that have been covalently attached to the surface of a protein. The high polymer grafting density and the potential for site-specific polymer growth that protein-ATRP achieves have enabled the synthesis of rationally designed functional protein-polymer conjugates $^{16}$ with dramatically enhanced stability ${ }^{14,1}, 18$ and therapeutic potential ${ }^{19,20}$. Growing polymers via ATRP from surface-initiated dissolved proteins is effective, but, the need to remove unreacted initiators, monomers, and catalysts in multiple purification steps has limited the automation of the process and its availability to a broad array of scientists. It can take weeks of careful synthesis and purification to generate just one protein-polymer variant. This challenge would be overcome by growing polymers from proteins that have been reversibly immobilized onto a solid surface.

The growth of reversibly immobilized peptides ${ }^{21}$ and nucleic acids from solid supports has driven the emergence of automated syntheses and combinatorial chemistry. Perhaps more importantly, peptides and nucleic acid can be generated by non-expert biologists who interface with a simple device instead of a chemical reactor. Reversible immobilization of polymerization precursors on solid supports, such as polystyrene beads, was the foundation from which these elegant syntheses were built. We have been interested in how to reversibly immobilize an entire protein on a solid support, then subsequently react the immobilized protein with ATRP initiators (or other compounds of interest) before site-specific polymer growth. The resulting protein-polymer conjugate could then be released in a pure form from the solid support. Protein-ATRP on reversible immobilization supports (PARIS) would be a powerful transformer of the synthesis and impact of protein-polymer conjugates.

There are a variety of proven chemistries that can reversibly bind proteins to solid supports and some have been used to create grafted-to protein-polymer conjugates ${ }^{22}$. Non-covalent interactions $^{23}$ and hydrophobic adsorption ${ }^{24}$ have been used, but the protein-support interactions are generally weak and proteinspecific. Immobilized metal-affinity chromatography is widely used for purification of proteins containing an affinity tag, such as polyhistidine, but this is only applicable for recombinantly labeled proteins ${ }^{25}$. In addition, stable covalent disulfide bonds between free thiol groups on proteins and solid supports can be reduced to release bound protein ${ }^{26}$. In order to develop broadly applicable and predictable PARIS syntheses of protein-polymer conjugates, we searched for a covalent and reversible coupling chemistry that could be used with almost any protein. Solid supports functionalized with dialkyl maleic anhydrides can react with primary amine groups on all proteins. This reversible reaction is $\mathrm{pH}$ dependent with the complex dissociating at low $\mathrm{pH}^{27}$. The chemistry is highly suitable for proteins that are stable for brief periods at low $\mathrm{pH}$ (3-4), but can also be tailored for $\mathrm{pH}$-sensitive proteins by increasing the reaction $\mathrm{pH}$ (5-6), albeit with lower efficiencies.

Herein, we explore immobilization of a protein's $N$-terminus $\alpha$ amino and/or lysine $\varepsilon$-amino groups to dialkyl maleic anhydridemodified agarose beads, followed by ATRP from subsequently initiator-modified $\varepsilon$-amino groups on the protein surface, prior to protein-polymer conjugate release after reducing $\mathrm{pH}$. PARISbased synthesis of grafted-from protein-polymer conjugates opens the door to automated combinatorial syntheses and high throughput screening of next generation protein-polymer hybrids.

\section{Results}

PARIS chemistry. Peptide synthesis from solid supports has traditionally used polystyrene resins $s^{28}$. Our initial experiments, however, demonstrated that non-specific hydrophobic adsorption of proteins to dialkyl maleic anhydride-modified polystyrene beads was significant. We therefore focused on hydrophilic supports that, we hypothesized, would reduce non-specific protein-support binding and ultimately be able to release a grown-from proteinpolymer hybrid. Agarose beads are hydrophilic and are stable at extremes of $\mathrm{pH}$, ionic strength, and in the presence of many denaturants. Currently, agarose beads are widely used in various chromatographic techniques for protein purification ${ }^{29}$. Dialkyl maleic anhydrides covalently react with primary amines above $\mathrm{pH}$ 6 and release below pH 6. Dialkyl maleic anhydride (DMA)modified agarose beads $(45-165 \mu \mathrm{m})$ were synthesized (Supplementary Fig. 1) and the $\mathrm{pH}$ dependence of on and off rates with a cyanine 3 amine fluorescent dye showed that up to $0.25 \mu$ mol $_{\text {DM }}$ $\mathrm{mL}^{-1}$ beads would be available for protein attachment during PARIS. We next performed each of the four major steps for PARIS (Fig. 1): protein immobilization onto the DMA-agarose beads $(\mathrm{pH}$ 6.0 or 8.0); ATRP-initiator immobilization on the agarosesupported protein (using $N$-2-bromo-2-methylpropanoyl- $\beta$-alanine $N^{\prime}$-oxysuccinimide bromide (NHS-Br) as previously described $^{17}$ ); surface-initiated ATRP to grow polymers from agarosesupported proteins ${ }^{15}$; and, cleavage of the resulting protein-polymer conjugates from the agarose supports (below $\mathrm{pH}$ 6). Each step of PARIS was characterized with fourier-transform infrared spectroscopy (FT-IR) (Supplementary Fig. 2).

Protein reaction with DMA-agarose. Proteins contain a number of accessible amino groups, including the $N$-terminal $\alpha$-amino and lysine side-chain $\varepsilon$-amino groups, that could potentially react with DMA-agarose beads to yield families of immobilized proteins. We hypothesized that we could preferentially target the protein-DMA reaction to the $N$-terminus of the protein by lowering the reaction $\mathrm{pH}$, thereby generating mostly homogeneous protein-polymer conjugates. Previous studies have shown that acylation of $\alpha$-amino groups ( $N$-terminus) is preferred at $\mathrm{pH} 6.5$ while $\varepsilon$-amino groups (lysine residues) react efficiently above $\mathrm{pH} 8.0^{30}$. Thus, we first investigated the $\mathrm{pH}$ dependence of DMA-lysine and DMA- $\mathrm{N}$-terminal group reactions using Cy5.5 amine and glycyl-glycyl-Cy3 (GGCy3) fluorescent dyes (Supplementary Figs. 3-7) as lysine and $N$-terminal mimics, respectively. The $\mathrm{p} K_{\mathrm{a}}$ of a lysine side chain is approximately $10.5-12.0$, while the $\mathrm{p} K_{\mathrm{a}}$ of the $\mathrm{N}$-terminus is approximately 7.8-8.0. Thus, at a $\mathrm{pH}$ below 8.0 , the $\mathrm{N}$-terminus will have increased nucleophilicity over lysine residues, and we hypothesized that this would lead to preferential immobilization of the aamino group to the DMA-agarose beads. Binding and release of these model dyes to the beads were determined as a function of $\mathrm{pH}$ and time (Supplementary Fig. 3). The data indicated that $\mathrm{N}$ terminal $\alpha$-amino-targeted protein binding to DMA beads was achievable at $\mathrm{pH} 6.0$, providing evidence for site-specific immobilization (Supplementary Discussion).

Next, we investigated the $\mathrm{pH}$ dependence of protein immobilization at $\mathrm{pH} 6.0$ and 8.0 and subsequent release over time from $\mathrm{pH} 3$ to 6 using chymotrypsin (CT) as a model protein. At $\mathrm{pH}$ 6.0 , both binding and release are occurring with variable rates 
(1) Protein immobilization

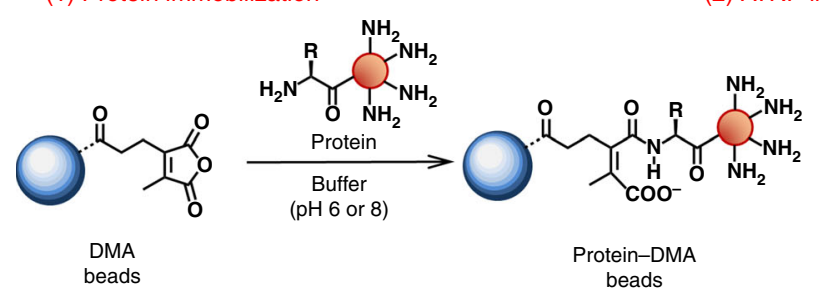

(3) Surface-initiated ATRP

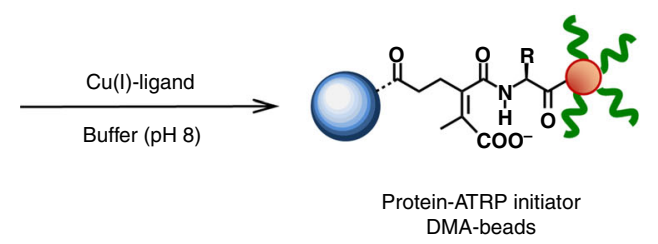

(4) Cleavage

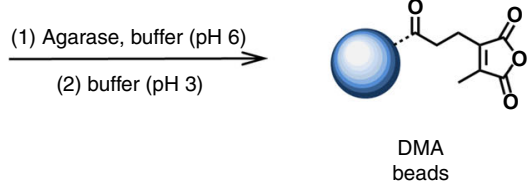

Protein-ATRP initiator DMA-beads
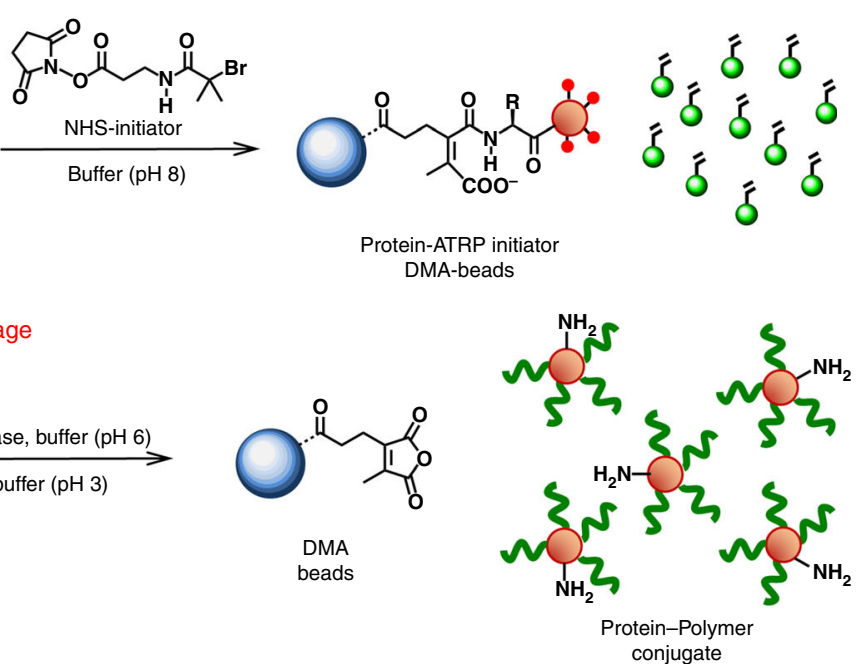

Fig. 1 Solid-phase synthesis of protein-polymer conjugates by protein-atom transfer radical polymerization on reversible immobilization supports (PARIS). Protein is first immobilized onto DMA-agarose beads (at $\mathrm{pH}$ 6-8) through surface accessible primary amines. Remaining primary amines on the protein are then modified with ATRP initiators (NHS-Br), followed by surface-initiated ATRP, to create functional protein-polymer conjugates. The resulting protein-polymer conjugates are detached from the DMA-agarose beads below $\mathrm{pH} 6$ and pass through a filter in pure form

depending on the reacting amino group. From the model dye data we knew that the binding rate at $\mathrm{pH} 6.0$ was greater than the release rate for the $N$-terminal mimic, while the opposite was true for the lysine mimic (Supplementary Table 1). The total concentration of bound protein after immobilization (1.82 \pm 0.12 and $4.02 \pm 0.11 \mathrm{mg} \mathrm{CT} \mathrm{mL}^{-1}$ beads at $\mathrm{pH} 6.0$ and 8.0, respectively) was determined using a bicinchoninic acid (BCA) assay. The concentration of immobilized protein achieved by reacting protein and DMA-agarose beads at $\mathrm{pH} 6.0$ was less than that from the reaction at $\mathrm{pH} 8.0$, again suggesting that this reaction could be site-specific since increased $\mathrm{pH}$ would increase the number of $\varepsilon$-amino groups that could react with the DMA, thereby significantly increasing the reaction stoichiometry.

Protein release kinetic studies were then performed over 60 min as a function of $\mathrm{pH}$ ranging ( $\mathrm{pH} 3$ to 6) for proteins initially immobilized at $\mathrm{pH} 6.0$ and 8.0 (Fig. 2). In both cases, total protein recovered and release rate increased with decreasing $\mathrm{pH}$ consistent with the model dye experiments. The percent of protein recovered was calculated after $60 \mathrm{~min}$ for each releasing $\mathrm{pH}$. The highest yields were 88 and $100 \%$ at $\mathrm{pH} 3$ for initial immobilizations at $\mathrm{pH} 6.0$ and 8.0, respectively, with the majority of release occurring within the first $5 \mathrm{~min}$ (Table 1). To ensure that CT was not inactivated by incubation in releasing buffer, residual activity was measured over time at $\mathrm{pH} 3$ (Supplementary Fig. 8). CT was able to recover full activity at neutral $\mathrm{pH}$ even after incubation for $3 \mathrm{~h}$ at $\mathrm{pH}$ 3. For more sensitive proteins, however, release can be performed at $\mathrm{pH} 6.0$ with $48 \%$ recovery. Moreover, in PARIS, the released product (a protein-polymer conjugate) may also have increased acid stability ${ }^{31}$, further protecting the protein from the acidity of releasing buffer. Herein, we show that protein can be immobilized to and subsequently released from DMA-agarose beads with high recovery and maintained activity. We also show that release is $\mathrm{pH}$ dependent, albeit with varying degrees, allowing reaction conditions to be customized to match a given protein's sensitivity to acid. Importantly, the most likely application of PARIS will be to perform combinatorial syntheses of protein-polymer conjugates for subsequent high throughput screening. In this application, the final yield is less relevant than the ease and speed of synthesis. As long as we can generate enough protein polymer to assay, PARIS will have served its purpose.
Following immobilization, the next step in PARIS was ATRPinitiator (NHS-Br) modification of the remaining immobilized accessible protein amino groups. Our assumption was that after the protein was immobilized, the remaining amino groups would be available for ATRP-initiator modification. We further surmised from the model dye experiments that the ATRP initiator would not react with the $N$-terminus since it was already selectively bound to the beads in the case of $\mathrm{pH} 6.0$ immobilization. CT has 15 primary amines: 14 lysine side chains and an additional $\alpha$-amino group on the $N$-terminus. The number of initiator modifications for CT immobilized at $\mathrm{pH} 6.0$ and 8.0 was determined to be 13 and 11, respectively, from matrix-assisted laser desorption/ionization time-of-flight mass spectrometry (MALDI-ToF MS) (Supplementary Fig. 9). We recently reported the use of MALDI-ToF MS after trypsin digestion of proteininitiator complexes to determine where initiators had reacted with proteins ${ }^{13}$. We used the same strategy to study modification sites on released initiator-modified CT. We did not observe modification of the $N$-terminal amino group by ATRP-initiator at $\mathrm{pH}$ 6.0, supporting our emerging view that DMA-agarose beads reacted with $\mathrm{CT}$ at the $\mathrm{N}$-terminal amino group at low $\mathrm{pH}$ (Supplementary Fig. 10). In contrast, we observed $N$-terminal modification with ATRP initiator after immobilization at $\mathrm{pH} 8.0$ indicated by the absence of the peptide fragment peak.

PARIS synthesis of CT-conjugates. Since the properties of CTpolymer conjugates have been studied in depth ${ }^{32-38}$, we next focused on synthesizing and characterizing CT-polymer conjugates grown within, then released from, DMA-agarose beads. For the polymer, we decided to grow poly(carboxybetaine methacrylate) (pCBMA), a hydrophilic and zwitterionic polymer, from the surface of the initiated and reversibly immobilized enzyme. Zwitterionic polymers stabilize CT against irreversible inactivation at extremes of temperatures and $\mathrm{pH}{ }^{17,39}$.

We expected that CT-pCBMA conjugates would grow from initiator sites on protein-DMA-agarose beads. We were particularly interested in whether the $\mathrm{pH}$ of immobilization and the agarose beads themselves would impact the structure and function of the subsequently released enzyme. The chemical structure of CT-pCBMA was initially characterized with ${ }^{1} \mathrm{H}$ NMR and FT-IR (Supplementary Figs. 11, 12). We further compared 


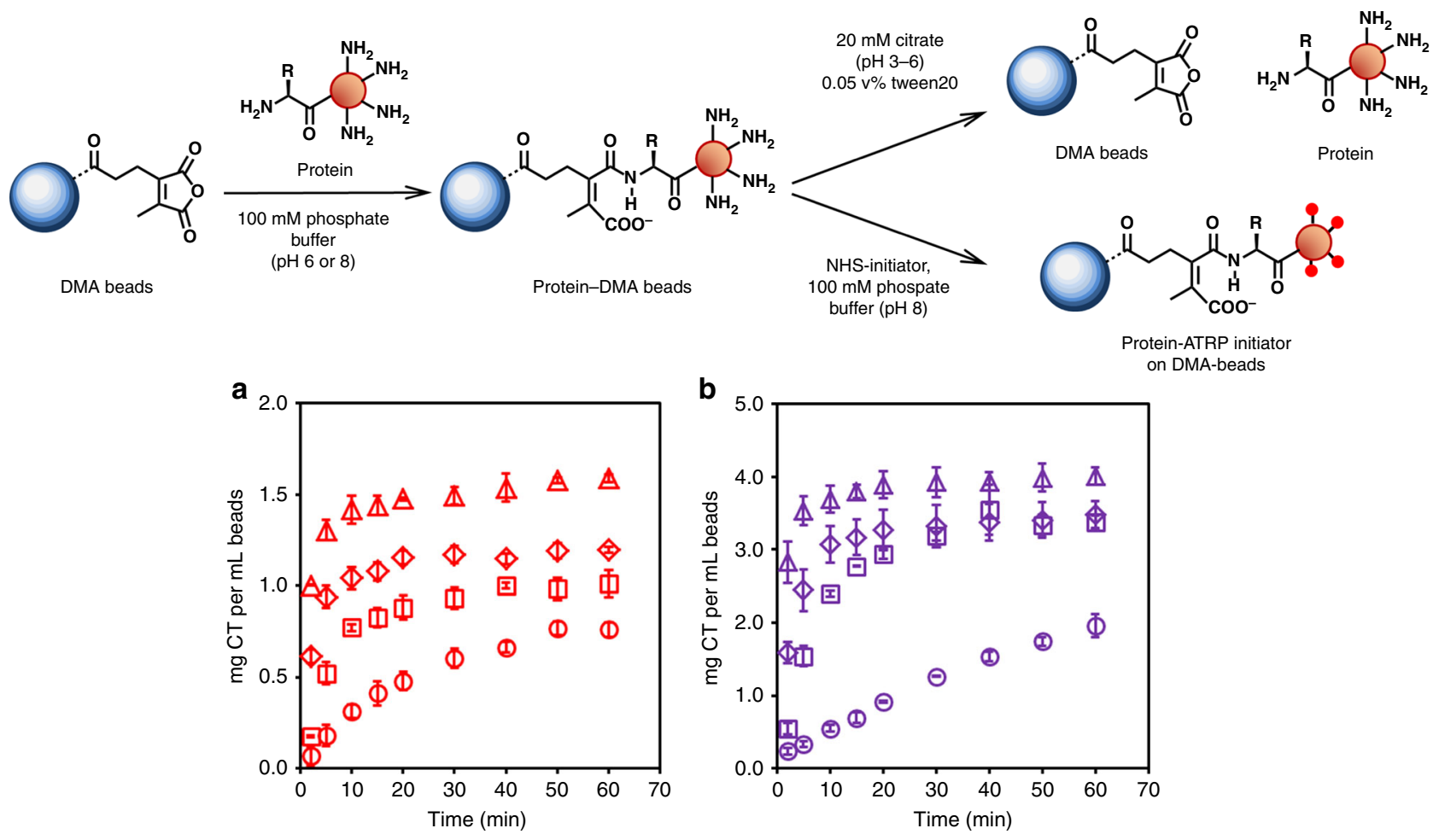

Fig. 2 Reversible protein immobilization to DMA-agarose beads and ATRP initiator modification. a Chymotrypsin release kinetics as a function of pH (3-6) after initial immobilization at pH 6.0 (red, determined by microBCA protein assay) and $\mathbf{b}$ after initial immobilization at pH 8.0 (purple, determined by microBCA assay). In both plots, release was performed by incubation at pH 3 (open triangle), $\mathrm{pH} 4$ (open diamond), pH 5 (open square), and pH 6 (open circle). The amount of recoverable protein and release rate increased as $\mathrm{pH}$ decreased. Error bars represent standard deviation from triplicate measurements

the released PARIS-CT conjugates to both solution-based CTpCBMA conjugates and native CT (Fig. 3). Following release from the DMA-agarose beads, protein concentration was determined spectroscopically. We first characterized released CT-pCBMA conjugate hydrodynamic diameter $\left(D_{\mathrm{h}}\right)$ using dynamic light scattering (DLS). The released conjugates grew in $D_{\mathrm{h}}$ from $4.4 \mathrm{~nm}$ (native CT) to approximately $9 \mathrm{~nm}$, independent of immobilization $\mathrm{pH}$. Solution-based CT-pCBMA conjugates were slightly larger than PARIS-synthesized conjugates (Table 2). We further characterized the conjugates through acid hydrolysis to cleave the polymer followed by gel permeation chromatography (GPC) showing polymer molecular weights of 9.2 and 8.2 $\mathrm{kDa}$ for CT immobilized at $\mathrm{pH} 6.0$ and 8.0, respectively with low polydispersity indices (PDI) for each.

We further compared the activity of released PARIS-CT conjugates to native CT and CT-pCBMA grown in solution. The turnover number and Michaelis constant $\left(k_{\text {cat }}\right.$ and $\left.K_{\mathrm{M}}\right)$ showed that all conjugates had similar activities with $N$-succinyl-L-Ala-LAla-L-Pro-L-Phe- $p$-nitroanilide (suc-AAPF-pNA) (Table 2). Since the PARIS conjugates immobilized at pH 6.0 and 8.0 had similar activities, the location of protein-bead immobilization did not significantly alter CT activity. Naturally, if polymer growth from the terminal amino group was performed on a protein that was sensitive to $N$-terminal modification, we would expect the activity of the conjugate to be lower from PARIS conjugates immobilized at $\mathrm{pH}$ 6.0. It is also worth noting that protein-polymer conjugates typically have reduced catalytic efficiencies through a combined decrease in $k_{\text {cat }}$ due to structural stiffening $^{40}$ and decrease in $K_{\mathrm{M}}$ due to the polymer's superhydrophilicity ${ }^{17}$. The overall catalytic productivity, $k_{\text {cat }} / K_{\mathrm{M}}$, of PARIS CT-pCBMA was similar to both solution-synthesized CTpCBMA and native CT.
Table 1 Protein recovered in releasing buffer from pH 3-6

\begin{tabular}{lll} 
Releasing pH & $\begin{array}{l}\text { Percent recovery from } \\
\text { pH 6.0 immobilization }\end{array}$ & $\begin{array}{l}\text { Percent recovery from } \\
\text { pH 8.0 immobilization }\end{array}$ \\
\hline pH 3 & $87.8 \pm 5.9$ & $99.8 \pm 4.1$ \\
pH 4 & $68.8 \pm 4.4$ & $86.5 \pm 5.3$ \\
pH 5 & $55.6 \pm 5.5$ & $84.1 \pm 3.1$ \\
pH 6 & $41.8 \pm 3.5$ & $47.8 \pm 4.1$ \\
\hline
\end{tabular}

The release rate and total amount of protein recovered are $\mathrm{pH}$ dependent with the highest recovery at $\mathrm{pH} 3$ after $60 \mathrm{~min}$. Error bars indicate standard deviation from triplicate measurements

Errors indicate standard deviation from triplicate measurements

Next, we sought to demonstrate that PARIS conjugates maintained the same stabilizing effect as conventionally synthesized protein-polymer conjugates in solution. Protein-polymer conjugates synthesized in solution have shown enhanced stability to extremes of $\mathrm{pH}^{41}$, temperatures ${ }^{18}$, and organic solvents ${ }^{42}$ due to the protective polymer coating. PARIS-CT conjugates significantly enhanced the thermostability of the enzyme at $50^{\circ}$ C (Fig. 3). Native CT was irreversibly inactivated after approximately $2 \mathrm{~h}$ at $50{ }^{\circ} \mathrm{C}$. Both PARIS CT-pCBMA and solution-based CT-pCBMA had significantly increased stability. Interestingly, PARIS conjugates that were initially immobilized at $\mathrm{pH} 6.0$ were significantly more stable after $6 \mathrm{~h}$ at $50{ }^{\circ} \mathrm{C}$ than those from $\mathrm{pH}$ 8.0. Previous studies have shown that many proteins have regions that are particularly susceptible to stabilityimpacting modifications and in many proteins the $N$-terminus is the most thermally sensitive region ${ }^{43-46}$. Additionally, enzymes with increased thermostability are often more hydrophobic ${ }^{47,48}$. Since the $\mathrm{N}$-terminus in CT was located in a largely hydrophobic 

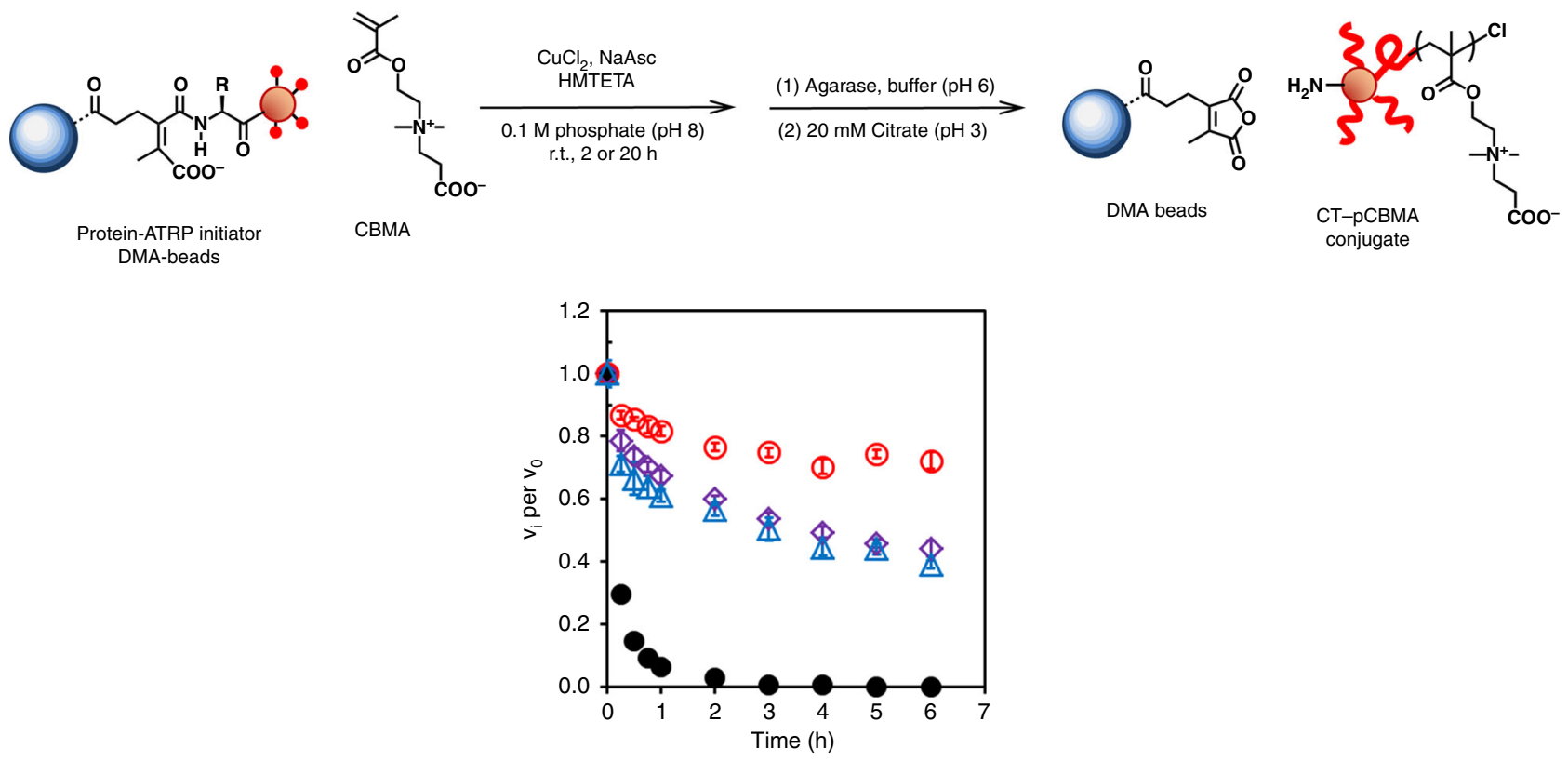

Fig. 3 Properties of released PARIS-synthesized protein-polymer conjugates. Irreversible inactivation of native $\mathrm{CT}$ and $\mathrm{CT}-\mathrm{pCBMA}$ at $50^{\circ} \mathrm{C}$. $\mathrm{CT}-\mathrm{pCBMA}$ immobilized at pH 6.0 and polymerized for $2 \mathrm{~h}$ (red open circle), CT-pCBMA immobilized at pH 8.0 and polymerized for $2 \mathrm{~h}$ (purple open diamond), CT - $\mathrm{pCBMA}$ by solution synthesis (blue open triangle), and native $\mathrm{CT}$ (black closed circle). Samples were incubated in $100 \mathrm{mM}$ sodium phosphate buffer ( $\mathrm{pH}$ 8.0, $50^{\circ} \mathrm{C}$ ) at $3.9 \mu \mathrm{M} \mathrm{CT}$ and residual activity was measured over $6 \mathrm{~h}$. All CT-pCBMA conjugates showed enhanced thermostability compared to native CT. CT-pCBMA immobilized at pH 6.0 with a free $\mathrm{N}$-terminus showed the highest thermostability. Error bars represent standard deviation from triplicate measurements

\begin{tabular}{|c|c|c|c|c|c|c|c|}
\hline $\begin{array}{l}\text { CT immobilization } \\
\text { (pH) }\end{array}$ & $\begin{array}{l}\text { Released CT-pCBMA } \\
\text { (mg CT per mL beads) }\end{array}$ & $\begin{array}{l}D_{h}^{c} \\
(n m)\end{array}$ & $\begin{array}{l}\text { Cleaved polymer } \\
M_{n}(k D a) ;\left(M_{w} / M_{n}\right)\end{array}$ & $\begin{array}{l}\text { Estimated } \\
\text { conjugate } M_{w} e^{e} \\
(k D a)\end{array}$ & $\begin{array}{l}k_{\text {cat }}^{f} \\
\left(s^{-1}\right)\end{array}$ & $\begin{array}{l}K_{M}^{f} \\
(\mu M)\end{array}$ & $\begin{array}{l}k_{\mathrm{cat}} / K_{\mathrm{M}}{ }^{f} \\
\left(\mathrm{~s}^{-1} \mu \mathbf{M}^{-1}\right) \\
\end{array}$ \\
\hline 6 & $0.56 \pm 0.02$ & $9.2 \pm 2.4$ & $9.2 ;(1.27)$ & 115.7 & $33.3 \pm 1.0$ & $65.5 \pm 8.2$ & $0.508 \pm 0.065$ \\
\hline 8 & $1.23 \pm 0.01$ & $9.1 \pm 1.9$ & $8.2 ;(1.26)$ & 133.1 & $34.6 \pm 1.2$ & $70.4 \pm 10.5$ & $0.491 \pm 0.075$ \\
\hline Native CT & - & $4.4 \pm 1.3$ & - & - & $34.6 \pm 1.4$ & $80.3 \pm 13.1$ & $0.431 \pm 0.072$ \\
\hline \multicolumn{8}{|c|}{$\begin{array}{l}\text { a CT-pCBMA conjugate was prepared by solution-based method } \\
\text { b The concentration of released conjugate based on CT per } 1 \mathrm{~mL} \text { of beads (estimated by UV absorption assay) indicating that there are more possible binding sites at pH } 8.0 \text { than at pH } 6.0 \\
\text { c Hydrodynamic diameters (number intensity) of the native CT and CT-pCBMA conjugates were measured using dynamic light scattering in } 20 \mathrm{mM} \text { sodium citrate }(\mathrm{pH} 3.0) \text { at } 25^{\circ} \mathrm{C} \text { showed an increase } \\
\text { in conjugate size over native CT } \\
\text { d Number average molar mass of cleaved pCBMA and polydispersity index from GPC } \\
\text { e Estimated conjugate molecular weight from GPC data } \\
\text { f Michaelis-Menten kinetic values for CT-catalyzed hydrolysis of suc-AAPF-pNA were determined by nonlinear curve-fitting of plots of initial rate versus substrate concentration using Enzfitter software. } \\
\text { Conjugates synthesized by PARIS did not alter activity in comparison to solution-synthesized CT-pCBMA and native CT }\end{array}$} \\
\hline
\end{tabular}

area, disruption of this hydrophobicity by initiator modification and consequent hydrophilic polymer growth could have decreased the thermostability of the $\mathrm{pH}$ 8.0 PARIS CT-pCBMA.

ATRP polymerization kinetics. We next explored whether DMA-agarose beads used in PARIS disrupted ATRP reaction kinetics. Thus, ATRP kinetics of PARIS and solution-synthesized conjugates were compared (Tables 3-4). Polymer growth was monitored over $60 \mathrm{~min}$ for a fixed monomer concentration of 25 $\mathrm{mM}$ by measuring $D_{\mathrm{h}}$ of conjugates at specified time points using DLS (Table 3 and Supplementary Fig. 13). Additionally, polymers were cleaved from the conjugates at each specified time point, and their molecular weights and PDIs were measured using GPC (Supplementary Fig. 14). Polymer molecular weight did not increase significantly after $5 \mathrm{~min}$ indicating that the ATRP reaction was fast and completed within the first $5 \mathrm{~min}$. Comparison of PARIS and solution-based conjugates showed similar overall polymer growth, however, PARIS conjugates displayed lower PDIs. The agarose bead pore size used in PARIS was approximately $30 \mathrm{~nm}$, which could have provided a uniform microenvironment during chain propagation leading to lower PDIs and more uniform conjugates. In conventional solution-based ATRP, polymer molecular weight can be tuned to a desired value by increasing the monomer to initiator ratio during the ATRP reaction. To show that conjugate size could be easily varied by PARIS, the monomer concentration was systematically increased from 12.5 to $100 \mathrm{mM}$ and conjugate $D_{\mathrm{h}}$, polymer molecular weights, and PDIs were determined for a $60 \mathrm{~min}$ reaction time (Table 4). As expected, conjugate $D_{\mathrm{h}}$ and polymer molecular weight increased with increasing monomer concentration for both PARIS and solution-based conjugate synthesis (each maintaining low PDIs) (Supplementary Figs. 13, 14). In summary, we were excited to observe that for pCBMA, highly uniform conjugates were synthesized by PARIS within $5 \mathrm{~min}$, polymer 
Table 3 PARIS and solution-based conjugate ATRP kinetics

\begin{tabular}{|c|c|c|c|c|}
\hline \multirow[t]{2}{*}{ Sample ${ }^{a}$} & \multirow{2}{*}{$\begin{array}{l}D_{\mathbf{h}}{ }^{b} \\
(\mathrm{~nm})\end{array}$} & \multicolumn{3}{|c|}{ Cleaved pCBMAc } \\
\hline & & $M_{n}$ & $M_{w}$ & PDI \\
\hline \multicolumn{5}{|l|}{ Solution } \\
\hline $5 \min$ & $12.3 \pm 4.2$ & 10100 & 14400 & 1.42 \\
\hline $10 \mathrm{~min}$ & $13.5 \pm 3.9$ & 9800 & 13900 & 1.44 \\
\hline $20 \mathrm{~min}$ & $12.8 \pm 7.5$ & 10000 & 14700 & 1.47 \\
\hline $40 \mathrm{~min}$ & $11.1 \pm 7.3$ & 9800 & 14200 & 1.45 \\
\hline $60 \mathrm{~min}$ & $11.3 \pm 7.8$ & 11000 & 16700 & 1.50 \\
\hline \multicolumn{5}{|l|}{ PARIS } \\
\hline $5 \min$ & $7.3 \pm 1.2$ & 9600 & 12300 & 1.28 \\
\hline $10 \min$ & $7.9 \pm 2.5$ & 9900 & 12800 & 1.29 \\
\hline $20 \mathrm{~min}$ & $9.3 \pm 1.3$ & 9600 & 12500 & 1.30 \\
\hline $40 \mathrm{~min}$ & $8.6 \pm 2.0$ & 10000 & 13300 & 1.33 \\
\hline $60 \mathrm{~min}$ & $9.4 \pm 1.4$ & 10600 & 14700 & 1.39 \\
\hline
\end{tabular}

Fixed monomer concentration of $25 \mathrm{mM}$. Chain propagation was completed within 5 min for CTpCBMA for both PARIS and solution-based approaches. Polymers synthesized by PARIS also had lower dispersities than solution-based

molecular weights were predictably controlled, and PARIS conjugates were similar, perhaps even more homogeneous, compared to solution-synthesized conjugates.

PARIS synthesis of protein conjugates. Although our results with CT conjugates synthesized by PARIS were exciting, an important step was to demonstrate that PARIS could be applied to a breadth of unrelated proteins. We sought to demonstrate that solution-synthesized conjugates were nearly identical to PARISsynthesized conjugates. To do this, we selected a series of proteins with varying sizes, structures, and $\mathrm{N}$-terminii accessibility: lysozyme $\left(\mathrm{Lyz}, \quad M_{\mathrm{w}, \text { monomer }}=14.3 \mathrm{kDa}\right)$, avidin $\left(M_{\mathrm{w}, \text { tetramer }}=68\right.$ $\mathrm{kDa}$ ), acetylcholinesterase $\left(\mathrm{AChE}, M_{\mathrm{w}, \text { tetramer }}=272 \mathrm{kDa}\right)$, and uricase (Uox, $M_{\mathrm{w} \text {,tetramer }}=140 \mathrm{kDa}$ ). As with CT, we first determined whether the reaction between DMA-agarose and protein was $\mathrm{N}$-terminus specific for each protein. Our combined data from all proteins showed that the immobilization reaction was $N$ terminus selective at $\mathrm{pH} 6.0$, as long as the $\alpha$-amino group was surface accessible, and was independent of protein size and quaternary structure (Supplementary Figs. 15, 18, Supplementary Table 2, and Supplementary Discussion). Initiator-modified proteins were also characterized by MALDI-ToF MS to determine the number of modification sites after initial immobilization at $\mathrm{pH} 6.0$ and 8.0 (Supplementary Figs. 19-21). After successful protein-ATRP with pCBMA, followed by release, the protein-polymer conjugates were fully characterized (Table 5). The percent of recovered conjugate was decreased in comparison to the prior released native protein experiments, with the highest conjugate recovery obtained from the smallest starting protein size ( $51 \%$ for lysozyme). This result was not surprising since larger conjugates could become more trapped inside the pores after polymer growth, thus hindering full release. We are currently exploring a number of methods to optimize release. For example, agarose bead pore size can be increased to accommodate larger proteins, multiple incubation steps in releasing buffer can be performed in series, or the ratio of releasing buffer to agarose bead solution can be increased. We have also been encouraged by early results with agarase-induced release optimization.

Hydrodynamic diameters were also similar for each PARISsynthesized and solution-synthesized conjugate pair. Polymers were also cleaved and analyzed using GPC to provide complete characterization. All polymers maintained low PDIs whether synthesized by PARIS or in solution.

We also were interested in whether each of the PARISsynthesized conjugates would have the same activity as solutionsynthesized conjugates. We note here that in this paper we were not
Table 4 PARIS and solution-based conjugate ATRP kinetics

\begin{tabular}{|c|c|c|c|c|}
\hline \multirow[t]{2}{*}{ Sample ${ }^{a}$} & \multirow{2}{*}{$\begin{array}{l}D_{h}^{b} \\
(n m)\end{array}$} & \multicolumn{3}{|c|}{ Cleaved pСBMA ${ }^{c}$} \\
\hline & & $M_{n}$ & $M_{\mathrm{w}}$ & PDI \\
\hline \multicolumn{5}{|l|}{ Solution } \\
\hline $12.5 \mathrm{mM}$ & $9.0 \pm 2.9$ & 8200 & 9900 & 1.18 \\
\hline $25 \mathrm{mM}$ & $11.8 \pm 2.4$ & 11100 & 15100 & 1.35 \\
\hline 50 mM & $13.6 \pm 4.3$ & 16100 & 25600 & 1.61 \\
\hline $100 \mathrm{mM}$ & $17.0 \pm 8.4$ & 27900 & 48800 & 1.77 \\
\hline \multicolumn{5}{|l|}{ PARIS } \\
\hline $12.5 \mathrm{mM}$ & $7.4 \pm 3.9$ & 7000 & 7700 & 1.10 \\
\hline $25 \mathrm{mM}$ & $9.4 \pm 2.5$ & 9600 & 12500 & 1.30 \\
\hline 50 mM & $13.5 \pm 3.2$ & 15200 & 21500 & 1.43 \\
\hline $100 \mathrm{mM}$ & $15.2 \pm 2.3$ & 23400 & 36000 & 1.53 \\
\hline
\end{tabular}

seeking to optimize conjugate activity for each of the proteins used. Activity assays were performed, specific for each enzyme (Supplementary Tables 3-6), and activities were reported as a ratio of PARIS-synthesized to solution-synthesized conjugates (Table 5e). In all cases, PARIS conjugates had maintained activities compared to solution-based conjugates. Additionally, lysozyme and uricase conjugates synthesized by PARIS had twice the activity over their solution-based counterparts. We have not performed extensive enough experiments in order to be able to claim that PARIS generates more active conjugates, but the data are promising. For acetylcholinesterase, we discovered that the enzyme was sensitive to release at $\mathrm{pH} 3$, but successful release at $\mathrm{pH} 5$ enabled a comparison with solution-synthesized conjugate (Supplementary Fig. 22). Overall, we were pleased to observe that conjugate synthesis via PARIS chemistry was not only suitable for a breadth of proteins, but also easily tunable for a specific protein's sensitivity. While we have not yet focused on yield optimization, the PARIS strategy is not limited to the release chemistry we selected in this initial demonstration of solid-state protein-ATRP. The PARIS data were comparable to conventional solution-generated data in terms of both physical and functional bioconjugate properties. PARIS is a reliable protein-polymer conjugate synthesis method that would be straightforward for any biologist to perform.

Facile automated one-pot PARIS. We developed PARIS in order to be able to generate protein-polymer conjugates in hours versus weeks, and to simplify and automate the chemistry involved. The conceptual attractiveness of flowing reactants into a column reactor, removing unreacted initiator, removing unreacted monomers, and purifying the conjugates by release from the beads drove us to design a PARIS-flow reactor (Fig. 4a). CT was bound to the DMA-agarose beads, reacted with initiator, and then released from the DMA beads in the reactor after polymerization. PARIS synthesis of CT-pCBMA in the flow reactor was compared to batch synthesis. Our data showed that conjugates synthesized in batch-mode and flow-mode had similar structure and function. The $D_{\mathrm{h}}$ of the conjugates released from the automated flow-based reactor were 8.7 and $9.2 \mathrm{~nm}$ for CT initially immobilized at $\mathrm{pH} 6.0$ and 8.0, respectively (Table 6). Similarly (and in agreement with results from the batch synthesis), both PARIS conjugates synthesized in the flow reactor had enhanced thermostability at $50^{\circ} \mathrm{C}$ relative to native $\mathrm{CT}$, while the most thermostable conjugate was CT-pCBMA that had been immobilized at $\mathrm{pH}$ 6.0.

Conventional protein-polymer conjugates that are grown from proteins require initiator modification, followed by days of separation and purification of initiator-modified proteins from 
Table 5 PARIS synthesis and characterization of ranging proteins

\begin{tabular}{|c|c|c|c|c|c|}
\hline Protein & Protein on beads ${ }^{a}$ & $\begin{array}{l}\text { Released } \\
\text { protein-pCBMA }\end{array}$ & $D_{h}^{c}$ & Cleaved Polymerd & Ratio of activitye \\
\hline & $\begin{array}{l}\text { (mg protein per } \mathrm{mL} \\
\text { beads) }\end{array}$ & $\begin{array}{l}\text { ( } \mathbf{m g} \text { protein per } \mathbf{m L} \\
\text { beads) (\% } \\
\text { recovery) }\end{array}$ & (nm) (solution) & $\begin{array}{l}M_{n}(k D a) \\
\text { (solution) }\end{array}$ & (PARIS: solution) \\
\hline Lysozyme & 1.89 & $0.97(51 \%)$ & $9.4 \pm 1.8(7.1 \pm 2.6)$ & $19.8(1.37)(15.0(1.26))$ & $1.94 \pm 0.13$ \\
\hline Avidin & 3.54 & $1.05(30 \%)$ & $13.2 \pm 2.8(21.7 \pm 6.4)$ & $13.2(1.30)(16.1(1.34))$ & $1.01 \pm 0.14$ \\
\hline Chymotrypsin & 2.01 & $0.89(44 \%)$ & $8.1 \pm 0.7(10.9 \pm 1.4)$ & $10.6(1.39)(11.0(1.50))$ & $1.03 \pm 0.24$ \\
\hline Acetylcholinesterase & 0.79 & $0.16(20 \%)$ & $13.0 \pm 2.0(13.9 \pm 5.2)$ & $14.5(1.35)(7.2(1.33))$ & $1.09 \pm 0.08$ \\
\hline Uricase & 0.43 & $0.09(21 \%)$ & $10.9 \pm 1.7(12.5 \pm 5.0)$ & $32.4(1.50)(14.7(1.30))$ & $2.33 \pm 0.15$ \\
\hline
\end{tabular}

a

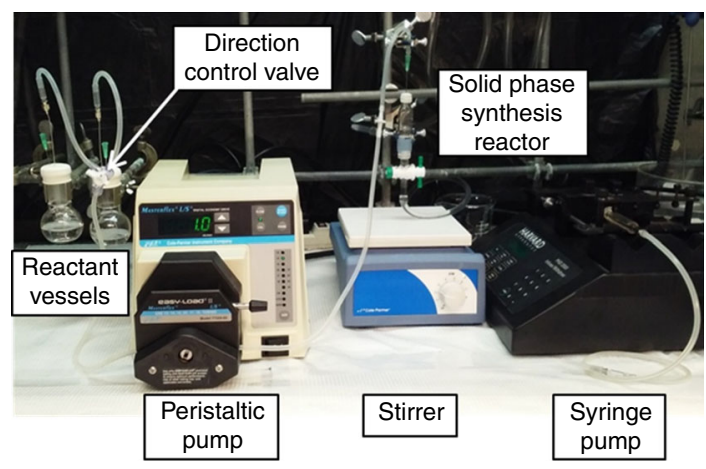

b

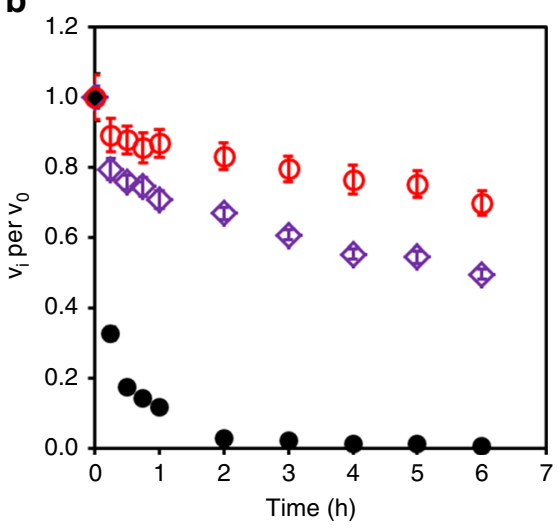

Fig. 4 Automated one-pot rapid PARIS protein-polymer conjugate synthesis and properties. a The experimental setup of a flow reactor for PARIS. b Irreversible inactivation of native $\mathrm{CT}$ and $\mathrm{CT}-\mathrm{pCBMA}$ at $50^{\circ} \mathrm{C}$. CT-pCBMA synthesized in the flow reactor immobilized at $\mathrm{pH} 6.0$ (red open circle) or pH 8.0 (purple open diamond) and native $\mathrm{CT}$ (black closed circle) were incubated in $100 \mathrm{mM}$ sodium phosphate buffer $\left(\mathrm{pH} 8.0,50{ }^{\circ} \mathrm{C}\right.$ ) at $3.9 \mu \mathrm{M} \mathrm{CT}$ for $6 \mathrm{~h}$. Both CT-pCBMA conjugates showed enhanced thermostability compared to native CT and CT-pCBMA immobilized at pH 6.0 with a free $\mathrm{N}$-terminus showed the highest thermostability similar to batch mode studies. Error bars represent standard deviation from triplicate measurements

Table 6 Characterization of CT conjugates by PARIS flow reactor

\begin{tabular}{|c|c|c|c|c|c|c|}
\hline CT immobilization & $\begin{array}{l}\text { Protein on } \\
\text { beads }^{a}\end{array}$ & $\begin{array}{l}\text { Released CT- } \\
\text { initiatorb }\end{array}$ & $\begin{array}{l}\text { Number of initiators on } \\
\text { the conjugate }\end{array}$ & $\begin{array}{l}\text { Released CT-pCBMA } \\
\text { by UV abs d }\end{array}$ & $\begin{array}{l}\text { Released CT-pCBMA } \\
\text { by activity }\end{array}$ & $D_{h}^{f}$ \\
\hline (pH) & $\begin{array}{l}\text { ( } \mathrm{mg} C T \text { per } \mathrm{mL} \\
\text { beads) }\end{array}$ & $\begin{array}{l}\text { (mg CT per } \mathrm{mL} \\
\text { beads) }\end{array}$ & & (mg CT per $\mathrm{mL}$ beads) & (mg CT per mL beads) & $(\mathrm{nm})$ \\
\hline 6 & 1.1 & 0.6 & 7.2 & 0.37 & 0.13 & $8.7 \pm 0.1$ \\
\hline 8 & 2.2 & 1.7 & 10.4 & 1.53 & 0.96 & $9.2 \pm 0.4$ \\
\hline \multicolumn{7}{|c|}{$\begin{array}{l}\text { a Concentration of immobilized CT determined by a microBCA protein assay. The concentration of } \mathrm{CT} \text { on the beads at } \mathrm{pH} 6.0 \text { is less than pH } 8.0 \text { indicating more possible binding sites at } \mathrm{pH} 8.0 \\
\text { b Concentration of released CT-initiator determined by a microBCA protein assay } \\
\text { c Average number of initiators per CT determined by fluorescamine amine assays using standard protocols } \\
\mathrm{d} \text { Concentration of released conjugates estimated by UV absorption } \\
\text { e Concentration of released conjugates estimated by enzyme activity using suc-AAPF-pNA as a substrate } \\
\text { f Hydrodynamic diameter of the CT-pCBMA conjugates was measured using dynamic light scattering in } 20 \mathrm{mM} \text { sodium citrate (pH } 3.0 \text { ) at } 25^{\circ} \mathrm{C} \text { showing an increase in conjugate size over native } \mathrm{CT} \\
\left(D_{\mathrm{h}}=4.4 \mathrm{~nm} \text {, number distribution) }\right.\end{array}$} \\
\hline
\end{tabular}

excess initiator, and then 2-4 days of polymerization and final purifications. The flow reactor experiment described above was completed in less than $6 \mathrm{~h}$. While the individual steps of conjugate synthesis between solution-based and PARIS-based approaches were similar, the PARIS purification steps were rapid and readily automated. This reduction in synthesis and purification time, coupled with our ability to multiplex the system, removed the complexity barrier from protein-polymer conjugate synthesis. It is currently difficult to predict how polymer conjugation will affect the resulting conjugate's overall function. Since PARIS conjugates were similar in structure and function to solution-based conjugates, an attractive feature of the flow reactor design was that high throughput synthesis would allow more rapid screening of a multitude of protein-polymer conjugates.

PARIS is a synthetic approach that allows solid-phase synthesis of grafted-from protein-polymer conjugates. PARIS generates 
conjugates with similar structure and function to traditional protein-ATRP in solution. Importantly, PARIS can be performed in a simple flow reactor, opening the door to automated and combinatorial protein-polymer conjugate syntheses. We believe that PARIS will have a significant impact on the accessibility of protein-polymer conjugate synthesis to a broad array of protein scientists and engineers.

\section{Methods}

The experiments were not randomized and the investigators were not blinded to allocation during experiments and outcome assessment. If not stated otherwise, measurements were performed in triplicate and error bars represent standard deviation.

Materials. $\alpha$-CT from bovine pancreas (type II), Lysozyme from chicken egg white, Acetylcholinesterase from Electrophorus electricus (electric eel, type VI-S), Uricase from porcine liver (type V), and Agarase from Pseudomonas atlantica were purchased from Sigma Aldrich (St Louis, MO). Avidin from Gallus gallus egg white was purchased from Lee biosolutions (Maryland Heights, MO). Protein surface active ATRP initiator (NHS-Br) was prepared as described previously ${ }^{15}$.

Preparation of dialkyl maleic anhydride (DMA) agarose beads. All materials were purchased from Sigma Aldrich (St Louis, MO) and used without further purification unless stated otherwise. Aminated agarose beads ( $\omega$ -

Aminohexyl-Sepharose $4 \mathrm{~B}, 10 \mathrm{~mL}$, swollen, $7-12 \mu \mathrm{mol} \mathrm{NH} \mathrm{mL}^{-1}$ beads) were washed with deionized water $(30 \mathrm{~mL} \times 2), 20 \mathrm{mM}$ citric acid $(30 \mathrm{~mL} \times 2)$ and 100 $\mathrm{mM}$ sodium phosphate buffer $(\mathrm{pH} 9,30 \mathrm{~mL} \times 2)$. A pre-incubated solution of 2,5dihydro-4-methyl-2,5-dioxo-3-furanpropanoic acid ( $44 \mathrm{mg}, 240 \mu \mathrm{mol}$, TCI America, Philadelphia, PA), EDC. $\mathrm{HCl}(46 \mathrm{mg}, 240 \mu \mathrm{mol})$ and 1-hydroxybenzotriazole hydrate $(32 \mathrm{mg}, 240 \mu \mathrm{mol})$ in dimethylformamide at $0{ }^{\circ} \mathrm{C}$ for $30 \mathrm{~min}$ was added to the aminated agarose solution with triethylamine $(70 \mu \mathrm{L}, 500 \mu \mathrm{mol})$, and the mixture was shaken at room temperature for $30 \mathrm{~min}$. The beads were washed with deionized water $(30 \mathrm{~mL} \times 3), 20 \mathrm{mM}$ citric acid $(30 \mathrm{~mL} \times 3)$ and deionized water $(30 \mathrm{~mL} \times 2)$. To block unmodified amine groups, the beads were incubated with acetic anhydride $(71 \mu \mathrm{L}, 500 \mu \mathrm{mol})$ and triethylamine $(70 \mu \mathrm{L}, 500 \mu \mathrm{mol})$ in deionized water $(30 \mathrm{~mL})$ at room temperature for $30 \mathrm{~min}$. The beads were then washed as previously described then stored in the refrigerator.

Quantitative analysis of accessible DM group on beads. Prepared DMA beads $(10 \mu \mathrm{L})$ were placed in a solution of $40 \mu \mathrm{M}$ Cyanine 3 amine (Lumiprobe, Hallandale Beach, FL) in $100 \mathrm{mM}$ sodium phosphate buffer ( $\mathrm{pH} 8$ ) containing $0.05 \mathrm{v} / \mathrm{v} \%$ Tween $20(500 \mu \mathrm{L})$ and shaken at room temperature for $60 \mathrm{~min}$. Beads were settled by centrifugation and the supernatant was aspirated. The beads were then washed with $100 \mathrm{mM}$ sodium phosphate $(\mathrm{pH} 8)$ containing $0.05 \mathrm{v} / \mathrm{v} \%$ Tween $20(1 \mathrm{~mL} \times 5)$. After removing the supernatant, $20 \mathrm{mM}$ sodium citrate $(\mathrm{pH} 3)$ containing $0.05 \mathrm{v} / \mathrm{v}$ $\%$ Tween $20(1 \mathrm{~mL})$ was added to the beads and shaken at room temperature for 60 min. Supernatant fluorescence intensities from the releasing solution were measured at an excitation of $550 \mathrm{~nm}$ and an emission of $570 \mathrm{~nm}$ with $10 \mathrm{~nm}$ bandwidths by a Safire2 plate reader (Tecan, Group Ltd.). Concentrations were calculated from standard curves.

Preparation of glycyl-glycyl-Cy3 (GGCy3). $N, N^{\prime}$-Diisopropylcarbodiimide (770 $\mu \mathrm{L}, 5.0 \mathrm{mmol}$ ) was added to a solution of Boc-GlyGly-OH (Bachem America, Torrance, CA, $920 \mathrm{mg}, 4.0 \mathrm{mmol}$ ) and $N$-hydroxysuccinimide (NHS, $575 \mathrm{mg}, 5.0$ $\mathrm{mmol})$ in dichloromethane $(50 \mathrm{~mL})$ at $0{ }^{\circ} \mathrm{C}$. The solution was stirred at room temperature overnight. Precipitated urea was filtered out and the filtrate was evaporated to remove dichloromethane under vacuum. Boc-GlyGly-NHS was isolated by recrystallization in 2-propanol with a $63 \%$ yield verified with proton nuclear magnetic resonance spectroscopy (Supplementary Figs. 5-7) recorded in $\mathrm{CDCl}_{3}$ using a $300 \mathrm{MHz}$, Bruker Avance in the NMR facility located in Center for Molecular Analysis, Carnegie Mellon University, Pittsburgh, USA. The solution of Boc-GlyGly-NHS $(16 \mathrm{mg}, 48 \mu \mathrm{mol})$ in chloroform $(40 \mathrm{~mL})$ was added to a solution of Cyanine 3 amine $(25 \mathrm{mg}, 40 \mu \mathrm{mol})$ and triethylamine $(7 \mu \mathrm{L}, 50 \mu \mathrm{mol})$ in dimethyl sulfoxide (DMSO; $100 \mu \mathrm{L}$ ) and stirred at room temperature overnight. The mixture was washed with $0.5 \mathrm{~N}$ hydrochloric acid $(\mathrm{HCl})$ aq. $(50 \mathrm{~mL} \times 2)$, saturated $\mathrm{NaHCO}_{3}$ $(50 \mathrm{~mL} \times 2)$, and saturated $\mathrm{NaCl}(50 \mathrm{~mL} \times 2)$, then dried with $\mathrm{MgSO}_{4} . \mathrm{After}_{\mathrm{MgSO}_{4}}$ removal by filtration, Boc-GlyGly-Cy3 was isolated by evaporating chloroform under vacuum with an $89 \%$ yield verified by ${ }^{1} \mathrm{H}$ NMR. The mixture of Boc-GlyGly-Cy3 $(30 \mathrm{mg}, 35.6 \mu \mathrm{mol})$ in $4 \mathrm{M} \mathrm{HCl}, 1,4$-dioxane $(80 \mu \mathrm{L})$, and 1,4dioxane $(920 \mu \mathrm{L})$ was stirred at room temperature for $4 \mathrm{~h}$. GlyGlyCy3 was obtained by evaporation of dioxane under vacuum with an $98 \%$ yield verified with ${ }^{1} \mathrm{H}$ NMR. GGCy3, oily compound, ${ }^{1} \mathrm{H}$ NMR $\left(300 \mathrm{MHz} \mathrm{CDCl}_{3}\right) \delta 1.4-1.9$ (broad, $14 \mathrm{H}$, $7 \times \mathrm{CH}_{2}$ and $12 \mathrm{H}, \mathrm{Cy} 3-\mathrm{CH}_{3}$ ), 2.5 (broad, $2 \mathrm{H}, \mathrm{CH}_{2}$ ), 3.2 (broad, $4 \mathrm{H}, 2 \times \mathrm{CH}_{2}$ ), 3.8 (broad, $3 \mathrm{H}, \mathrm{Cy} 3 \mathrm{~N}-\mathrm{CH}_{3}$ ), 4.0-4.3 (broad, $2 \mathrm{H}, \mathrm{CH}_{2}$ and $4 \mathrm{H}, 2 \times \mathrm{Gly}^{\alpha}$ ), 6.8 (broad, $2 \mathrm{H}, \mathrm{CH}=\mathrm{CH}$ ), 7.3 and 7.4 (broad, $8 \mathrm{H} \mathrm{Cy} 3-\mathrm{Ar} \mathrm{H}$ ), 8.2 (broad, $1 \mathrm{H}$, amide), 8.4 (broad, $1 \mathrm{H}, \mathrm{CH}=\mathrm{CH}-\mathrm{CH}$ ), 8.6 (broad, $2 \mathrm{H}$, amide) ppm; ${ }^{13} \mathrm{C} \mathrm{NMR}(75 \mathrm{MHz}$, DMSO- $\left._{6}\right) \delta 25.2,25.7,26.1,26.8,28.0,28.2,28.7,28.9,29.0,29.1,29.7,34.0,35.0$,
$36.1,38.7,39.7,42.9,49.0,49.2,103.9,105.6,116.0,125.7,127.5,128.5,131.2,140.5$, $141.9,169.3,170.1,173.8$ ppm; IR (NaCl plate) 2956, 2924, 2853, 1712, 1651, 1557 1493, 1456, 1416 and $1376 \mathrm{~cm}^{-1}$; HRMS $(m / z):[\mathrm{M}-2 \mathrm{H}]^{+}$calcd. for $\mathrm{C}_{40} \mathrm{H}_{57} \mathrm{~N}_{6} \mathrm{O}_{3}{ }^{2}$ , 670.46; found, 670.94 .

GGCy3 and Cy5.5 amine binding to DMA beads. Five hundred microliters of GGCy3 or Cy5.5 amine solution (Lumiprobe, Hallandale Beach, FL, $40 \mu \mathrm{M}$ in 100 $\mathrm{mM}$ sodium phosphate $(\mathrm{pH} 5-8)$ containing $0.05 \mathrm{v} / \mathrm{v} \%$ Tween 20 and $20 \mu \mathrm{L}$ of DMA beads were shaken at room temperature. The supernatant was removed at given incubation times and the beads were washed with incubation buffer $(1 \mathrm{~mL} \times$ 2 ) followed by washing buffer ( $100 \mathrm{mM}$ sodium phosphate ( $\mathrm{pH} 8)$ containing 0.05 $\mathrm{v} / \mathrm{v} \%$ of Tween $20(1 \mathrm{~mL} \times 3)$ to remove residuals. The beads were incubated in releasing buffer ( $1 \mathrm{~mL}, 20 \mathrm{mM}$ sodium citrate $(\mathrm{pH} 3)$ containing $0.05 \mathrm{v} \%$ Tween 20$)$ at room temperature for $1 \mathrm{~h}$, and supernatant fluorescence intensities were measured with a Safire2 plate reader (GGCy3: excite $550 \mathrm{~nm}$, emit $570 \mathrm{~nm}$; Cy5.5: excite $670 \mathrm{~nm}$, emit $707 \mathrm{~nm}$ ). Concentrations were calculated from standard curves. See Supplementary Methods.

GGCy3 and Cy5.5 amine release from DMA beads. Thirty microliters of DMA beads were pre-incubated with $750 \mu \mathrm{L}$ of GGCy3 or Cy5.5 amine solution $(40 \mu \mathrm{M}$ in $100 \mathrm{mM}$ sodium phosphate $(\mathrm{pH} 8)$ containing $0.05 \mathrm{v} / \mathrm{v} \%$ Tween 20$)$. The supernatant was removed and the dye bound beads were washed with the washing buffer. The beads were incubated in releasing buffer $(1.5 \mathrm{~mL})$ at room temperature and fluorescence intensities of supernatant aliquots $(100 \mu \mathrm{L})$ at given time point were measured at wavelengths mentioned above. See Supplementary Methods.

Protein immobilization on DMA beads. A volume of $4.5 \mathrm{~mL}$ of protein solution (2 $\mathrm{mg} \mathrm{mL}^{-1}, 100 \mathrm{mM}$ sodium phosphate ( $\mathrm{pH} 6$ or 8 ) containing $0.05 \mathrm{v} / \mathrm{v} \%$ Tween 20 was combined with $1.5 \mathrm{~mL}$ of DMA beads in the solid phase peptide synthesis vessel $(10 \mathrm{~mL}$ capacity, Chemglass) and shaken at room temperature or in refrigerator for $30 \mathrm{~min}$. After removing the supernatant, the beads were washed with incubation and washing buffers. The amount of immobilized protein on the DMA beads was determined using a Micro BCA Protein Assay Kit (ThermoFisher Scientific). The sample solution and beads $(10 \mu \mathrm{L})$ in $500 \mu \mathrm{L}$ of deionized water were mixed with micro BCA working reagent $(500 \mu \mathrm{L})$ and incubated at $60^{\circ} \mathrm{C}$ for $1 \mathrm{~h}$. The absorbance at $562 \mathrm{~nm}$ was recorded by a UV-VIS spectrometer (Lambda 2, Perkin Elmer).

ATRP initiator modification onto immobilized protein. Two hundred millimolar of ATRP initiator, NHS-Br ${ }^{15}$ (NHS-Br) solution in DMSO $(225 \mu \mathrm{L})$ was added to the suspension of the protein immobilized DMA beads $(1.5 \mathrm{~mL})$ in $100 \mathrm{mM}$ sodium phosphate $(\mathrm{pH} 8,4.5 \mathrm{~mL})$ and shaken at room temperature for $30 \mathrm{~min}$. The beads were washed with $100 \mathrm{mM}$ sodium phosphate $(\mathrm{pH} 8,5 \mathrm{~mL} \times 5)$. Estimation of immobilized ATRP initiator on protein was carried out by BCA and fluorescamine assays. The beads $(20 \mu \mathrm{L})$ were incubated in $20 \mathrm{mM}$ sodium citrate $(\mathrm{pH}$ 3) containing $0.05 \mathrm{v} / \mathrm{v} \%$ of Tween $20(200 \mu \mathrm{L})$ at room temperature for $1 \mathrm{~h}$. BCA protein assay was used to determine protein concentration in the supernatant as previously described. Fluorescamine assay was used to determine the number of bound initiators. Aliquots $(40 \mu \mathrm{L})$ of supernatant, $100 \mathrm{mM}$ sodium phosphate $(40$ $\mu \mathrm{L}, \mathrm{pH} 9)$, and fluorescamine solution in DMSO $\left(20 \mu \mathrm{L}, 3 \mathrm{mg} \mathrm{mL}^{-1}\right)$ were added into a 96-well plate and incubated at room temperature for $15 \mathrm{~min}$. Fluorescence intensities were measured at the excitation of $390 \mathrm{~nm}$ and emission of $470 \mathrm{~nm}$ with $10-\mathrm{nm}$ bandwidths by a Safire 2 plate reader. Concentration was determined using a standard curve.

Trypsin digestion of protein-initiator conjugates. Trypsin digests were used to generate peptide fragments from which protein-initiator attachment sites could be determined using matrix-assisted laser desorption/ionization time-of-flight (MALDI-ToF) mass spectrometry. Five proteins were studied. a-CT from bovine pancreas (type II), lysozyme from chicken egg white, acetylcholinesterase from Electrophorus electricus (electric eel, type VI-S), uricase from porcine liver (type V). Avidin from Gallus gallus egg white was purchased from Lee biosolutions (Maryland Heights, MO). Samples were digested according to the protocol described in the In-Solution Tryptic Digestion and Guanidination Kit. Briefly, $10-20 \mu \mathrm{g}$ of protein or protein-initiator complexes $\left(10 \mu \mathrm{L}\right.$ of a $2 \mathrm{mg} \mathrm{mL}^{-1}$ protein solution in deionized water) were added to $15 \mu \mathrm{L}$ of $50 \mathrm{mM}$ ammonium bicarbonate with $1.5 \mu \mathrm{L}$ of $100 \mathrm{mM}$ dithiothreitol in a $0.5 \mathrm{~mL}$ Eppendorf tube. The reaction was incubated for $5 \mathrm{~min}$ at $95^{\circ} \mathrm{C}$. Thiol alkylation was conducted by the addition of $3 \mu \mathrm{L}$ of $100 \mathrm{mM}$ iodoacetamide aqueous solution to the protein solution and incubation in the dark for $20 \mathrm{~min}$ at room temperature. Following incubation, $1 \mu \mathrm{L}$ of $100 \mathrm{ng}$ trypsin was added to the protein solution and the reaction was incubated at $37^{\circ} \mathrm{C}$ for $3 \mathrm{~h}$. Then, an additional $1 \mu \mathrm{L}$ of $100 \mathrm{ng}$ trypsin was subsequently added. The reaction was terminated after a total reaction time of $5 \mathrm{~h}$ by the addition of trifluoroacetic acid (TFA). Digested samples were purified using $\mathrm{ZipTipC}_{18}$ microtips and eluted with $2 \mu \mathrm{L}$ of matrix solution $\left(20 \mathrm{mg} \mathrm{mL}^{-1}\right.$ sinapinic acid in $50 \%$ acetonitrile with $0.1 \%$ TFA) directly onto a MALDI-ToF plate for subsequent analysis. The molecular weight of the expected peptide fragments before and after digestion was predicted using PeptideCutter (ExPASy Bioinformatics Portal, Swiss Institute of Bioinformatics). Peptide fragment containing the $\mathrm{N}$-terminal group was examined for modification. 
MALDI-ToF analysis. MALDI-ToF measurements were recorded using a PerSeptive Voyager STR MS with nitrogen laser $(337 \mathrm{~nm})$ and $20 \mathrm{kV}$ accelerating voltage with a grid voltage of $90 \%$. At least 300 laser shots covering the complete spot were accumulated for each spectrum. Sinapinic acid $\left(20 \mathrm{mg} \mathrm{mL}^{-1}\right)$ in $50 \%$ acetonitrile with $0.4 \%$ TFA was used as matrix. Protein solution $\left(0.5-1.0 \mathrm{mg} \mathrm{mL}^{-1}\right)$ was mixed with an equal volume of matrix and $2 \mu \mathrm{L}$ of the resulting mixture was loaded onto a silver sterling plate target. Apomyoglobin, cytochrome C, and aldolase were used as calibration samples. Extent of modification was determined by subtracting the protein-initiator conjugates $\mathrm{m} / \mathrm{z}$ values from native protein $\mathrm{m} / \mathrm{z}$ and dividing by the molecular weight of the initiator $\left(220.9 \mathrm{~g} \mathrm{~mol}^{-1}\right)$. Molecular weights of peptide fragments obtained in protein digests were determined after the solutions were purified by use of ZipTipC $_{18}$ microtips. Bradykinin fragment, angiotensin II (human) and insulin oxidized B chain (bovine) were used for calibration.

Surface-initiated ATRP from immobilized protein-immobilized. A suspension of DMA beads $(1.5 \mathrm{~mL}$ ) and carboxybetaine methacrylate (CBMA, $29 \mathrm{mg}, 125$ $\mu \mathrm{mol}$, TCI America) in $100 \mathrm{mM}$ sodium phosphate $(4.5 \mathrm{~mL}, \mathrm{pH} 8)$ in the synthesis vessel was sealed with a rubber septum and bubbled with nitrogen at room temperature for $30 \mathrm{~min}$. $500 \mu \mathrm{L}$ of deoxygenated catalyst solution $\left(\mathrm{CuCl}_{2}\right.$, sodium ascorbate, and 1, 1, 4, 7, 10, 10-hexamethyltriethylenetetramine (HMTETA, Supplementary Methods), similar conditions as in solution-based synthesis) was then added to the synthesis vessel under nitrogen. The mixture was sealed and shaken at room temperature for 1-2 h. The beads were washed with $100 \mathrm{mM}$ sodium phosphate $(\mathrm{pH} 8,5 \mathrm{~mL} \times 5)$

Protein-pCBMA releasing from DMA beads. Agarase solution $\left(15 \mu \mathrm{L}, 1 \mathrm{U}^{-1}\right)$ was added to a suspension of obtained protein-pCBMA beads $(1.5 \mathrm{~mL})$ in $100 \mathrm{mM}$ sodium phosphate $(\mathrm{pH} 6,985 \mu \mathrm{L})$ and rotated at room temperature overnight (Supplementary Fig. 23). To release, $20 \mathrm{mM}$ sodium citrate $(3.5 \mathrm{~mL}, \mathrm{pH}$ ) was added and rotated at room temperature for $1 \mathrm{~h} .100 \mathrm{mM}$ sodium phosphate buffer (pH 5) was used for releasing AChE-pCBMA from beads due to irreversible inactivation of $\mathrm{AChE}$ at low $\mathrm{pH}$ (details in Supplementary Methods). The supernatant containing protein-pCBMA conjugates was separated from the beads by filtration or centrifugation. Protein concentration in the supernatant was determined by UV absorption protein or BCA protein assay.

Native CT stability at pH 3. Native CT $(40 \mu \mathrm{M})$ was dissolved in $20 \mathrm{mM}$ citrate buffer $(\mathrm{pH} 3)$ and incubated at $25^{\circ} \mathrm{C}$. At given time points, aliquots $(10 \mu \mathrm{L})$ were removed and measured activity in $950 \mu \mathrm{L}$ of $100 \mathrm{mM}$ sodium phosphate buffer ( $\mathrm{pH}$ 8 ) and $40 \mu \mathrm{L}$ of suc-AAPF-pNA solution ( $10 \mathrm{mM}$ in DMSO) at $25^{\circ} \mathrm{C}$. The residual activity was calculated as a ratio of initial rates of hydrolysis reaction at given incubation time over the initial activity at time zero, which monitored by recording the increase in absorption at $412 \mathrm{~nm}$ using an UV-VIS spectrometer.

Solution-based synthesis of protein-pCBMA. Solution-based synthesis of CTpCBMA was carried out as described previously ${ }^{15,17}$. Briefly, a solution of CBMA ( $104 \mathrm{mg}, 0.45 \mathrm{mmol})$ and protein-initiator $(18-20 \mu \mathrm{mol}$ of initiator) in $100 \mathrm{mM}$ sodium phosphate $(20 \mathrm{~mL}, \mathrm{pH} 8)$ was sealed and bubbled with nitrogen gas in an ice bath for $30 \mathrm{~min}$. One milliliter of deoxygenated catalyst solution (described above) was then added to the polymerization reactor under bubbling nitrogen. The mixture was sealed and stirred at room temperature for $2 \mathrm{~h}$. The conjugate was isolated by dialysis with a $25 \mathrm{kDa}$ molecular weight cutoff dialysis tube in deionized water in a refrigerator for $24 \mathrm{~h}$ and then lyophilized.

Characterization of PARIS by FT-IR spectroscopy. $100 \mu \mathrm{L}$ of beads at each step of the PARIS synthesis were rinsed with deionized water $(1 \mathrm{~mL} \times 5)$, and then frozen and dried in vacuum. FT-IR spectra of each sample were obtained with an IR spectrometer using a $\mathrm{KBr}$ pellet.

Characterization released PARIS CT-pCBMA. Chemical structure of the released CT-pCBMA conjugate by PARIS was characterized by ${ }^{1} \mathrm{H}$ NMR and FT-IR measurements. In the ${ }^{1} \mathrm{H}$ NMR spectrum, the signals of polymer backbone chain were observed at 1.0-1.3 ( $3 \mathrm{H}$, methyl) and $2.1 \mathrm{ppm}(2 \mathrm{H}$, ethylene). The signals of carboxybetaine side chain (Supplementary Fig. 11) can be observed. In the IR spectrum, the absorption of ester group on the polymer chain was observed at $1727 \mathrm{~cm}^{-1}$, and the specific absorption of amide groups from CT were observed at $1643\left(v_{\mathrm{C}=\mathrm{O}}\right.$ : amide I) and $1550 \mathrm{~cm}^{-1}\left(\delta_{\mathrm{N}-\mathrm{H}}\right.$ : amide II $)$.

Cleavage of the grafted pCBMA from the conjugate. The grafted pCBMA was cleaved by acidic hydrolysis from the conjugate. Protein-pCBMA conjugate (10-20 mg) and $6 \mathrm{~N} \mathrm{HCl}$ aq. $(4-5 \mathrm{~mL})$ were placed in a hydrolysis tube. After three freeze-pump-thaw cycles, the hydrolysis was performed at $110^{\circ} \mathrm{C}$ for $24 \mathrm{~h}$ in vacuum. The cleaved polymer was isolated by dialysis using a $1 \mathrm{kDa}$ molecular weight cut off dialysis tube in deionized water and was then lyophilized. The molecular weight of the cleaved polymer was measured by GPC.
Determination of conjugate hydrodynamic diameter. DLS data were collected on a Malvern Zetasizer nano-ZS located in the Department of Chemistry, Carnegie Mellon University, Pittsburgh, PA. The hydrodynamic diameters of native protein and conjugate were measured three times ( 5 run to each measurement) in various buffers at room temperature. Reported values are number distribution intensities.

Determination of conjugate Michaelis-Menten kinetics. Suc-AAPF-pNA $(0-125 \mu \mathrm{L}$ of $9.60 \mathrm{mM}$ in DMSO) was mixed with sodium phosphate buffer $(865-950 \mu \mathrm{L}$ of $100 \mathrm{mM}, \mathrm{pH} 8)$. Native CT or conjugates solution $(10 \mu \mathrm{L}, 3.9 \mu \mathrm{M}$ of $\mathrm{CT}$ ) was added to the substrate solution. The initial substrate hydrolysis rate was monitored by recording the increase in absorbance at $412 \mathrm{~nm}$ using an UV-VIS absorbance spectrometer with a temperature-controlled cell holder at $25^{\circ} \mathrm{C}$. Michaelis-Menten parameters were determined by nonlinear curve fitting of initial rate versus substrate concentration plots using Enzfitter software.

Determination of enzyme thermostability. Native CT and conjugates (1.5-2.0 $\mathrm{mL}, 3.9 \mu \mathrm{M}$ of CT) were incubated in $100 \mathrm{mM}$ sodium phosphate buffer ( $\mathrm{pH} 8.0$ ) at $50{ }^{\circ} \mathrm{C}$. Aliquots $(10 \mu \mathrm{L})$ were removed and activity was measured using suc-AAPFpNA ( $40 \mu \mathrm{L}$ of $9.6 \mathrm{mM}$ in DMSO) in sodium phosphate buffer $(950 \mu \mathrm{L}$ of $100 \mathrm{mM}$, $\mathrm{pH} 8$ ) by UV-VIS spectroscopy with a temperature-controlled cell holder. Residual activity was calculated as a ratio of hydrolysis rate at a given incubation time over the initial hydrolysis rate for each sample.

Flow reactor CT immobilization on DMA beads. DMA beads $(1.5 \mathrm{~mL})$ and 20 $\mathrm{mM}$ citrate $(3.0 \mathrm{~mL}, \mathrm{pH} 2)$ were sealed in the flow reactor with a rubber septum. Deionized water was introduced into the reactor by a peristaltic pump at room temperature at a flow rate of $1 \mathrm{~mL} \mathrm{~min}^{-1}$ for $30 \mathrm{~min}$. CT $\left(2.0 \mathrm{mg} \mathrm{mL}^{-1}\right)$ in $100 \mathrm{mM}$ sodium phosphate ( $\mathrm{pH} 6$ or 8 ) containing $0.05 \mathrm{v} / \mathrm{v} \%$ Tween 20 was introduced into the reactor by a peristaltic pump at a flow rate of $1 \mathrm{~mL} \mathrm{~min}^{-1}$ for $30 \mathrm{~min}$ to bind the DMA beads. The beads were then washed with $100 \mathrm{mM}$ sodium phosphate $(\mathrm{pH}$ 8) containing $0.05 \mathrm{v} / \mathrm{v} \%$ Tween 20 for $30 \mathrm{~min}$

Flow reactor ATRP initiator modification on immobilized CT. $200 \mathrm{mM} \mathrm{NHS-Br}$ in DMSO was introduced into the reactor by a syringe pump at a flow rate of $8 \mu \mathrm{L}$ $\min ^{-1}$ for $30 \mathrm{~min}$. The sample was then washed with $100 \mathrm{mM}$ sodium phosphate $(\mathrm{pH})$ for $30 \mathrm{~min}$. An aliquot $(20 \mu \mathrm{L}$ of beads) was taken from the reactor for the BCA and fluorescamine assays.

Flow reactor surface-initiated ATRP from immobilized CT. A suspension of DMA beads $(1.5 \mathrm{~mL}$ ) and carboxybetaine methacrylate (CBMA, $29 \mathrm{mg}, 125 \mu \mathrm{mol})$ in $100 \mathrm{mM}$ sodium phosphate $(4.5 \mathrm{~mL}, \mathrm{pH} 8)$ was sealed in the synthesis vessel with a rubber septum and bubbled with nitrogen at room temperature for $30 \mathrm{~min}$. Five hundred microliters of deoxygenated catalyst solution $\left(\mathrm{CuCl}_{2}\right.$, sodium ascorbate, and HMTETA) was then added to the synthesis vessel under nitrogen. The mixture was sealed and stirred at room temperature for $2 \mathrm{~h}$ followed by washing with $100 \mathrm{mM}$ sodium phosphate $(\mathrm{pH} 8)$ at a flow rate $1 \mathrm{~mL} \mathrm{~min}^{-1}$ for $30 \mathrm{~min}$.

Flow reactor CT-pCBMA release from DMA beads. Agarase solution $(15 \mu \mathrm{L}, 1$ $\left.\mathrm{U} \mu \mathrm{L}^{-1}\right)$ was added to a suspension of CT-pCBMA beads $(1.5 \mathrm{~mL})$ in $100 \mathrm{mM}$ sodium phosphate $(\mathrm{pH} 6,985 \mu \mathrm{L})$ and was rotated at room temperature overnight To release, $20 \mathrm{mM}$ sodium citrate $(3.5 \mathrm{~mL}, \mathrm{pH} 3)$ was added and stirred at room temperature for $1 \mathrm{~h}$. The supernatant containing CT-pCBMA conjugates was separated from the beads by filtration. Protein concentration in the supernatant was determined by UV absorption and enzyme hydrolysis of $\mathrm{N}$-Succinyl-Ala-AlaPro-Phe $p$-nitroanilide (suc-AAPF-pNA) using a standard curve with native CT.

Data availability. All relevant data is included in the manuscript, Supplementary Information, or may be available upon author's request.

Received: 10 July 2017 Accepted: 24 January 2018

Published online: 27 February 2018

\section{References}

1. Abuchowski, A., Mccoy, J. R., Palczuk, N. C., Es, T. V. A. N. \& Davis, F. F. Effect of covalent attachment of polyethylene glycol on immunogenicity and circulating life of bovine liver catalase. J. Biol. Chem. 252, 3582-3586 (1976).

2. Abuchowski, A., Es, T. V., Palczuk, N. C. \& Davis, F. F. Alteration of immunological properties of bovine serum albumin by covalent attachment of poly(ethylene glycol). J. Control. Rel. 252, 3578-3581 (1977).

3. Wilson, P. Synthesis and applications of protein/peptide-polymer conjugates. Macromol. Chem. Phys. 218, 1600595 (2017).

4. O'Sullivan, A. et al. Pin28 use of peginterferon alfa-2b in chronic hepatitis C patients failing prior therapy: a costeffectiveness analysis. Value Health 11, A437 (2008). 
5. Nesbitt, A. et al. Mechanism of action of certolizumab pegol (CDP870): in vitro comparison with other anti-tumor necrosis factor a agents. Inflamm. Bowel Dis. 13, 1323-1332 (2007).

6. Hills, G. Industrial use of lipases to produce fatty acid esters. Eur. J. Lipid Sci. Technol. 105, 601-607 (2003).

7. Griengl, H., Schwab, H. \& Fechter, M. The synthesis of chiral cyanohydrins by oxynitrilases. Trends Biotechnol. 18, 252-256 (2000).

8. Harris, J. M. \& Chess, R. B. Effect of pegylation on pharmaceuticals. Nat. Rev. Drug Discov. 2, 214-221 (2003).

9. Isarov, S. A., Lee, P. W. \& Pokorski, J. K. 'Graft-to' protein/polymer conjugates using polynorbornene block copolymers. Biomacromolecules 17, 641-648 (2016).

10. Yang, Z., Domach, M., Auger, R., Yang, F. X. \& Russell, A. J. Polyethylene glycol-induced stabilization of subtilisin. Enzym. Microb. Technol. 18, 82-89 (1996).

11. Cobo, I., Li, M., Sumerlin, B. S. \& Perrier, S. Smart hybrid materials by conjugation of responsive polymers to biomacromolecules. Nat. Mater. 14, 143-159 (2014).

12. Gong, Y., Leroux, J. C. \& Gauthier, M. A. Releasable conjugation of polymers to proteins. Bioconjug. Chem. 26, 1179-1181 (2015).

13. Lele, B. S., Murata, H., Matyjaszewski, K. \& Russell, A. J. Synthesis of uniform protein-polymer conjugates. Biomacromolecules 6, 3380-3387 (2005).

14. Cummings, C., Murata, H., Koepsel, R. \& Russell, A. J. Tailoring enzyme activity and stability using polymer-based protein engineering. Biomaterials 34, 7437-7443 (2013).

15. Murata, H., Cummings, C. S., Koepsel, R. R. \& Russell, A. J. Polymer-based protein engineering can rationally tune enzyme activity, $\mathrm{pH}$-dependence, and stability. Biomacromolecules 14, 1919-1926 (2013).

16. Heredia, K. L. et al. In situ preparation of protein-'smart' polymer conjugates with retention of bioactivity. J. Am. Chem. Soc. 127, 16955-16960 (2005)

17. Cummings, C. S. et al. Design of stomach acid-stable and mucin bindingenzyme polymer conjugates. Biomacromolecules 18, 576-586 (2017).

18. Cummings, C., Murata, H., Koepsel, R. \& Russell, A. J. Dramatically increased $\mathrm{pH}$ and temperature stability of chymotrypsin using dual block polymer-based protein engineering. Biomacromolecules 15, 763-771 (2014).

19. Duncan, R. The dawning era of polymer therapeutics. Nat. Rev. Drug Discov. 2, 347-360 (2003).

20. Pelegri-Oday, E. M., Lin, E. W. \& Maynard, H. D. Therapeutic proteinpolymer conjugates: advancing beyond pegylation. J. Am. Chem. Soc. 136, 14323-14332 (2014).

21. Merrifield, R. B. Solid phase peptide synthesis. I. The synthesis of a tetrapeptide. J. Am. Chem. Soc. 85, 2149-2154 (1963).

22. Song, L. et al. A solid-phase PEGylation strategy for protein therapeutics using a potent FGF21 analog. Biomaterials 35, 5206-5215 (2014).

23. Bahulekar, R., Ayyangar, N. R. \& Ponrathnam, S. Polyethyleneimine in immobilization of biocatalysts. Enzym. Microb. Technol. 13, 858-868 (1991).

24. Caldwell, K. D., Axén, R., Bergwall, M. \& Porath, J. Immobilization of enzymes based on hydrophobic interaction. I. Preparation and properties of a beta-amylase adsorbate. Biotechnol. Bioeng. 18, 1573-88 (1976).

25. Porath, J. Immobilized metal ion affinity chromatography. Protein Expr. Purif. 3, 263-281 (1992).

26. Laurell, C. B., Thulin, E. \& Bvwater, R. P. Thiol-disulfide interchange chromatography using sepharose-linked thiol compounds to separate plasma proteins. Anal. Biochem. 81, 336-345 (1977).

27. Nieto, M. A. \& Palacián, E. Effects of temperature and $\mathrm{pH}$ on the regeneration of the amino groups of ovalbumin after modification with citraconic and dimethylmaleic anhydrides. Biochim. Biophys. Acta 749, 204-210 (1983).

28. Merrifield, B. The role of the support in solid phace peptide synthesis. $B r$. Polym. J. 16, 173-178 (1984).

29. Barbosa, O. et al. Strategies for the one-step immobilization-purification of enzymes as industrial biocatalysts. Biotechnol. Adv. 33, 435-456 (2015).

30. Gaudriault, G. \& Vincent, J. P. Selective labeling of alpha or epsilon-amino groups in peptides by the Bolton-Hunter reagent. Peptides 13, 1187-1192 (1992).

31. Murata, H., Cummings, C. S., Koepsel, R. R. \& Russell, A. J. Rational tailoring of substrate and inhibitor affinity via ATRP polymer-based protein engineering. Biomacromolecules 15, 2817-2823 (2014).

32. Günther, R., Thust, S., Hofmann, H.-J. \& Bordusa, F. Trypsin-specific acyl-4guanidinophenyl esters for a-chymotrypsin-catalysed reactions. Eur. J. Biochem. 267, 3496-3501 (2000).

33. Klibanov, A. M. Improving enzymes by using them in organic solvents. Nature 409, 241-246 (2001).

34. Falatach, R. et al. Why synthesize protein-polymer conjugates? The stability and activity of chymotrypsin-polymer bioconjugates synthesized by RAFT. Polym. (U. Kingd.) 72, 382-386 (2015).

35. Sandanaraj, B. S. et al. Noncovalent modification of chymotrypsin surface using an amphiphilic polymer scaffold: Implications in modulating protein function. J. Am. Chem. Soc. 127, 10693-10698 (2005).
36. Hong, J. et al. Conjugation of alpha-chymotrypsin on a polymeric hydrophilic nanolayer covering magnetic nanoparticles. J. Mol. Catal. B Enzym. 42, 99-105 (2006).

37. Kumar, A. \& Venkatesu, P. Overview of the stability of alpha chymotrypsin in different solvent media. Chem. Rev. 112, 4283-4307 (2012)

38. Hedstrom, L. Serine protease mechanism and specificity. Chem. Rev. 102, 4501-4523 (2002)

39. Zhang, Y. \& Cremer, P. S. Interactions between macromolecules and ions: the Hofmeister series. Curr. Opin. Chem. Biol. 10, 658-663 (2006).

40. Rivera-rivera, I., Barletta, G. \& Griebenow, K. Stabilization of alpha chymotrypsin upon PEGylation correlation with reduced structural dynamics. Biotechnol. Bioeng. 101, 1142-1149 (2009).

41. Thomas, P., Russell, A. \& Fersht, A. Tailoring the $\mathrm{pH}$ dependence of enzyme catalysis using protein engineering. Nature 318, 375-376 (1985).

42. Cummings, C. S., Murata, H., Matyjaszewski, K. \& Russell, A. J. Polymerbased protein engineering enables molecular dissolution of chymotrypsin in acetonitrile. ACS Macro Lett. 5, 493-497 (2016).

43. Chatterjee, P. \& Sengupta, N. Signatures of protein thermal denaturation and local hydrophobicity in domain specific hydration behavior: a comparative molecular dynamics study. Mol. Biosyst. 12, 1139-1150 (2016).

44. Jiang, X., Chen, G. \& Wang, L. Structural and dynamic evolution of the amphipathic $\mathrm{N}$-terminus diversifies enzyme thermostability in the glycoside hydrolase family 12. Phys. Chem. Chem. Phys. 18, 21340-50 (2016).

45. Wang, W. et al. A novel mechanism of protein thermostability: a unique Nterminal domain confers heat resistance to Fe/Mn-SODs. Sci. Rep. 4, 7284 (2014).

46. Šanderová, $\mathrm{H}$. et al. The N-terminal region is crucial for the thermostability of the G-domain of Bacillus stearothermophilus EF-Tu. Biochim. Biophys. Acta 1804, 147-155 (2010).

47. Ward, O. P. \& Moo-Young, M. Thermostable enzymes. Biotechnol. Adv. 6, 39-69 (1988)

48. Vieille, C. \& Zeikus, J. G. Thermozymes: identifying molecular determinants of protein structural and functional stability. Trends Biotechnol. 14, 183-190 (1996).

\section{Acknowledgements}

The authors acknowledge financial support provided by Carnegie Mellon University Center for Polymer-Based Protein Engineering.

\section{Author contributions}

H.M. synthesized the solid and solution-based protein-polymer conjugates, synthesized model dyes, performed and analyzed the binding/release fluorescence studies, characterized the protein-polymer conjugates for hydrodynamic diameter and activity, performed thermostability testing, and designed the flow reactor. S.C. performed the trypsin digestion studies of the five proteins and performed and analyzed MALDI-ToF MS data. S.L.B helped to design experiments and drafted the manuscript. A.R and K.M supervised the project and provided guidance.

\section{Additional information}

Supplementary Information accompanies this paper at https://doi.org/10.1038/s41467 018-03153-8.

Competing interests: The authors declare no competing financial interests.

Reprints and permission information is available online at http://npg.nature.com/ reprintsandpermissions/

Publisher's note: Springer Nature remains neutral with regard to jurisdictional claims in published maps and institutional affiliations.

Open Access This article is licensed under a Creative Commons Attribution 4.0 International License, which permits use, sharing, adaptation, distribution and reproduction in any medium or format, as long as you give appropriate credit to the original author(s) and the source, provide a link to the Creative Commons license, and indicate if changes were made. The images or other third party material in this article are included in the article's Creative Commons license, unless indicated otherwise in a credit line to the material. If material is not included in the article's Creative Commons license and your intended use is not permitted by statutory regulation or exceeds the permitted use, you will need to obtain permission directly from the copyright holder. To view a copy of this license, visit http://creativecommons.org/ licenses/by/4.0/

(C) The Author(s) 2018 